\title{
Fuel Consumption for Various Dishes for a Wood-Fueled and Charcoal Fueled Improved Stoves used in Rural Northern Ghana
}

\author{
Ali Moro ${ }^{1 *}$, Bernard Fei Baffoe ${ }^{2}$, Maxwell Dalaba ${ }^{3}$ and Abraham Oduro ${ }^{1}$ \\ ${ }^{1}$ Navrongo Health Research Centre, Ghana \\ ${ }^{2}$ Kwame Nkrumah University of Science and Technology, Ghana \\ ${ }^{3}$ The University of Health and Allied Sciences-Ho, Ghana
}

Submission: March 30, 2020; Published: June 25, 2020

*Corresponding author: Ali Moro, Navrongo Health Research Center, Navrongo-Ghana

\begin{abstract}
Up to 2.4 billion people (approximately 40\% of the earth's population) still depend on biomass as their main source of energy and currently, there are a wide variety of stove technologies and designs aimed at providing better cooking experience to end-users. The study design was cross-sectional, and data was collected between November to March of 2019 in the Kasena Nankana Districts. The study conducted 20 in-field uncontrolled cooking tests designed to assess the fuel consumption performance of the Ace stove and the Jumbo stove. Specific Fuel Consumption (SFC), Per Capita Biomass Consumption (PcBC) and Fuel consumption rate were calculated across a variety of meal types using the two stoves. An independent T-test was employed to determine the mean differences. The results showed that the Jumbo stove averaged $1.43 \pm 0.23 \mathrm{~kg}$ of fuel per a cooking event with a per capita annual consumption of $38.06-274.97 \mathrm{~kg}$ while the Ace stove averaged $0.31 \pm 0.04 \mathrm{~kg}$ per cooking event with a per capita consumption of $14.6-75.65 \mathrm{~kg}$. There was a statistically significant difference between the fuel consumption rate per kg of food prepared $(\mathrm{p}<0.001)$ between the Ace stove and the Jumbo stove (Figure 1).
\end{abstract}

Keywords: Biomass consumption; Ace stove, Jumbo stove; Demographic surveillance survey; Cookstoves; Economic incentives

\section{Introduction}

In 2015, the Navrongo health research center with its partners introduced 2 new stoves: The African Clean Energy (Ace) stove and the Greenway Jumbo as part of a study [refer to SD: plate $1 \& 2]$. Generally, the project aimed to understand the interaction between the following factors on the household's decision to adopt improved cookstoves: economic incentives ("prices"), social learning ("peers") and subjective beliefs ("perceptions") in technology adoption dynamics. The project was in two arms namely the P3 bio which involved rural households and the P3 Gas in the urban areas and involves the use of LPG.

The P3 bio was implemented in 50 clusters within the two Kasena Nankana Districts (KNDs) [1-5].

This paper sort to understand the fuel consumption characteristics of the two stoves in an uncontrolled setting.

\section{Materials and Methods}

The stove biomass consumption described herein was completed in the Kassena Nankana Municipal and the Kassena
Nankana West District (KND's) of the Upper East Region of Ghana (Figure 2).

\section{Study area}

The KNDs can be located on longitude $10^{\circ} 53^{\prime} 5^{\prime \prime} \mathrm{N}$ and Latitude $1^{\circ} 5^{\prime} 25^{\prime \prime} \mathrm{W}$. The climate in the region is arid and hot with an annual rainfall of about $950 \mathrm{~mm}$. The vegetation in this area is dominated by woody shrubs and grassland with one rainy season lasting from approximately May to October. Much of the land is used for subsistence agriculture, with corn and millet as the dominant crops cultivated. The study area is within the catchment area of the Navrongo Health Research Center (NHRC) which has conducted a district-wide Health and Demographic Surveillance Survey (HDSS) and several other research studies since 1993 [6].

The KNDs population is organized into settlements known as compounds and comprises multiple households belonging to a single lineage living together and presided over by a compound head (mostly a male figure). Inside these organized settlements are households made up of a sub-divided group of people that 
usually eat from a common cooking source. According to the Navrongo Health and Demographic Surveillance System (NHDSS), the population of the 2 districts is about 156,000 with about $80 \%$ living in rural areas while $20 \%$ are in more urban areas such as the central town of Navrongo. About $88 \%$ of rural households rely mainly on firewood as their main cooking fuel, while another $9 \%$ rely primarily on charcoal and only about $3 \%$ of households cook primarily with gas or electricity. The traditional cooking method in these rural areas is a three-stone open fire, with many households also using charcoal stoves [6].

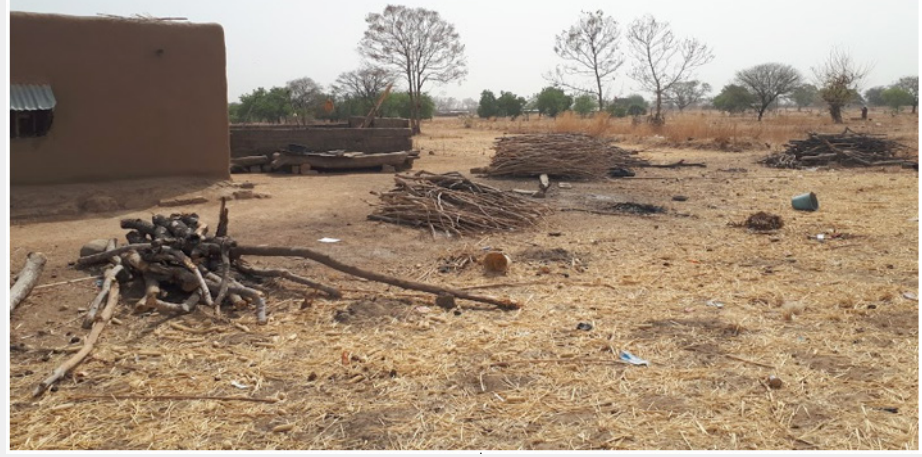

Figure 1: Firewood harvested by a household to be used.

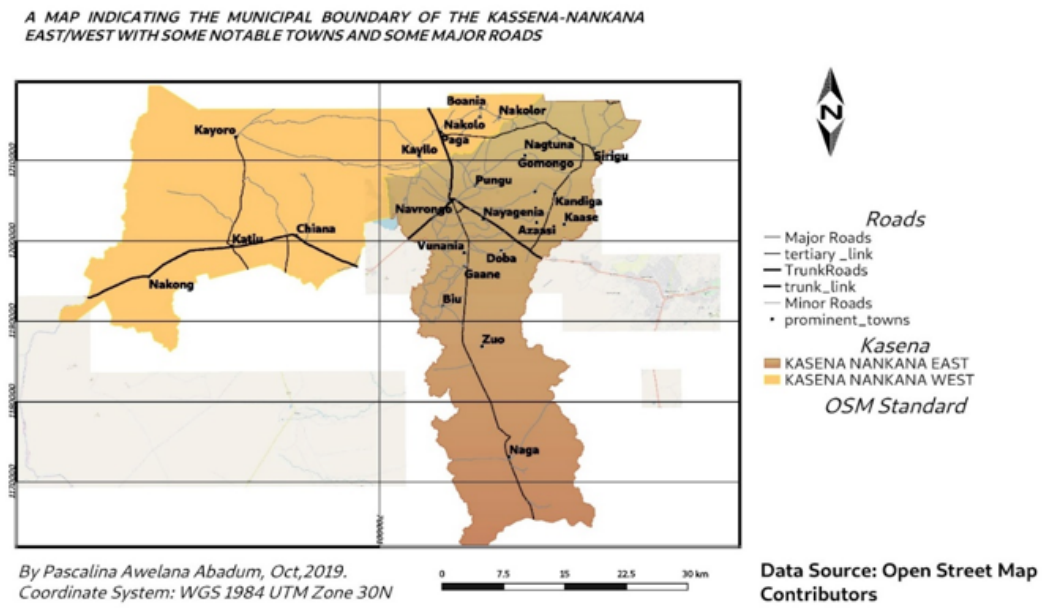

Figure 2: Map of the Kassena Nankana Districts.

\section{Study design}

The study design was cross-sectional. The Uncontrolled Cooking Test (UCT) method was also adopted for this study to gain a better understanding of the performance of the stoves and the cooking system over a wider range of variables. This method of cookstove test has been developed by the University of Johannesburg SeTAR center. In this method, the meal is not constrained, therefore the Cook is free to prepare what they want, how they want it, where they want and when they want. the UCT allows the cook to prepare a local dish of their size and type using local fuels. The cook's preferences inherently add to the test variability

\section{Sampling procedure}

The sampling technique employed in this study was the multi-stage sampling method. Ten (10) clusters out of the 50 P3 clusters were randomly sampled (2 each from the 5 NHDSS zones). Twenty (20) households within the 10 sampled clusters were again conveniently sampled.

\section{Cooking systems}

In-field stove performance testing was conducted on the two types of stoves (The Ace stove and the Jumbo stove). 


\section{Greenway Jumbo Stove}

This is a single burner, high-efficiency, portable, metallic and non-chimney cookstove (Plate 1). It is designed to suit large families and small cafeterias. This stove can use any type of solid biomass fuel such as cow dung, wood, and agricultural waste. It uses less fuel than traditional mud cookstoves and produces less smoke. It reduces the time and/or money users spend buying fuel or collecting and allowing for a more comfortable cooking experience (Figure 3).

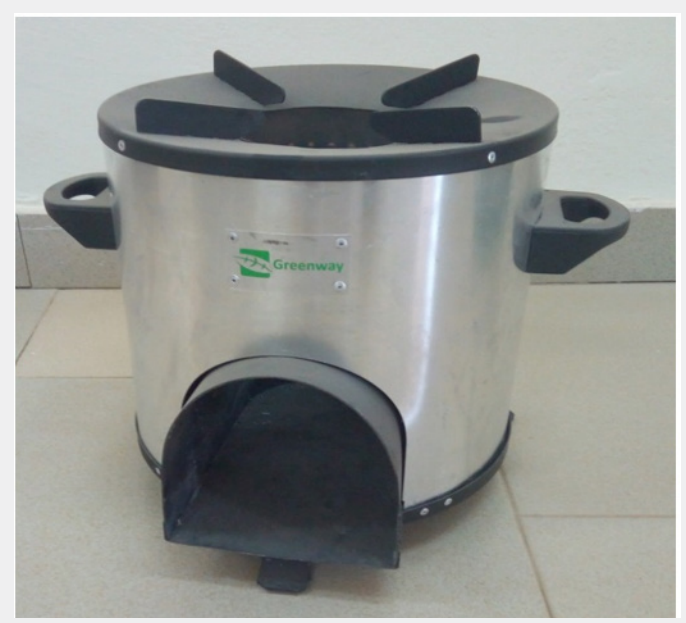

Figure 3: The Jumbo Stove.

Features of the Jumbo stove

a) Size: $12.4^{\prime \prime} \times 10.6^{\prime \prime} \times 11.6 "$.

b) Materials: Steel and Aluminum with Bakelite Handles.

c) Loading Capacity: $40 \mathrm{~kg}$.

d) Secondary Air Induction Mechanism: Yes.

e) Fuel Savings: $65 \%$.

f) Smoke Reduction: $70 \%$. g) Ergonomic front-loading design.

\section{ACE 1 Cook Stove}

The ACE 1 Solar Biomass cookstove is a multifunctional tool, combining a smoke-free cooking experience with LED lighting and access to energy for mobile devices (Plate 2). The stove comes in different colors and burns a variety of biomass fuels cleanly. The stove saves around $70 \%$ of fuel compared to traditional stoves (Figure 4).

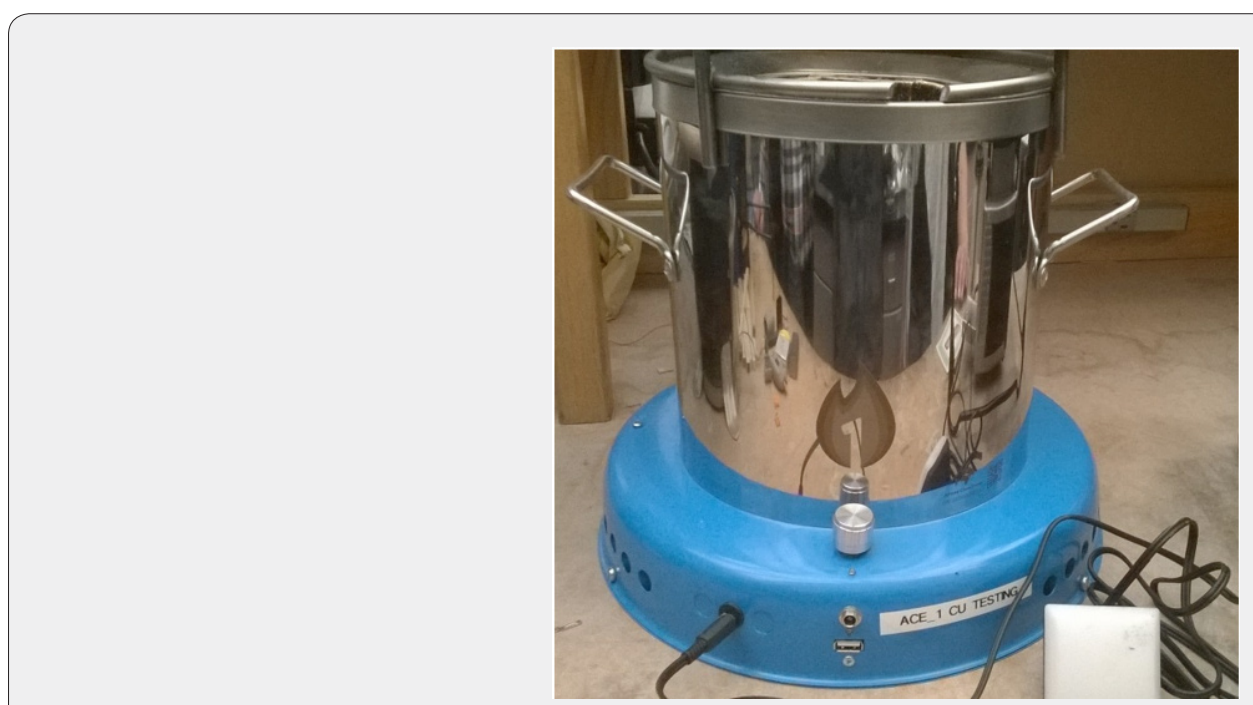

Figure 4: The Ace Stove. 
Features of the Ace 1 stove

a) Height: $32 \mathrm{~cm}$.

b) Diameter (at top of stove): $22.5 \mathrm{~cm}$.

c) Weight: $4.6 \mathrm{~kg}$.

d) Fuel Chamber Volume: $842 \mathrm{~cm}^{3}$.

e) Firepower: Max 4,000 - 5,000 watts, Min 2,000 - 3,000 watts.

f) Stove Body: Stainless Steel (grade 430).

g) Stove Base: Powder Coated Galvanized Steel. h) Pot Rest: Galvanized Steel.

(Figure 5) The Three-stone-stove using wood and agricultural waste is the primary stove in the study area with others using coalpot as a secondary stove [7]. Cooking fuel in the KND's is mostly firewood (plate 1) and charcoal sourced mostly from Vitellaria Paradoxa and shrub-branches. Although both stoves can burn all types of biomass (wood products and agricultural residues), charcoal and firewood were used by participants in this study for the Ace stove and the firewood respectively. A variety of means are prepared in the study area, but the common meal is rice and Tuo Zaafi (TZ). Meals are prepared in cast aluminum pots of different sizes depending on the size of the family.

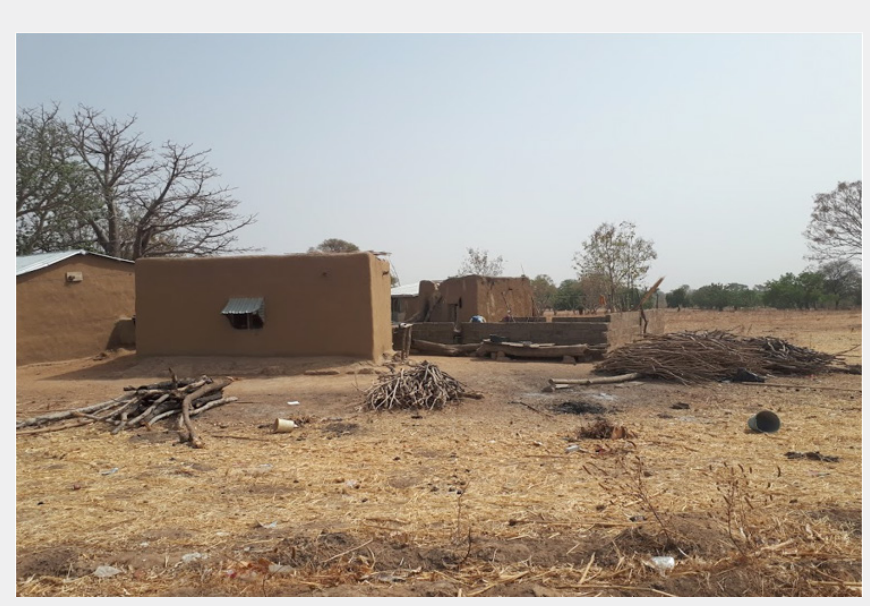

Figure 5: Firewood collected by a household to be used as cooking fuel.

\section{Performance metrics and fuel measurements}

A date was scheduled with the primary cook for the cooking event to be observed. The participant (primary cook) was given enough time to prepare for the day of the measurement. The participant then decides the time of day the meal is to be prepared (Breakfast, Lunch or Supper).

Before the test on the given day, any existing fire was extinguished, and the cooking area was cleared of char and wood. The sufficient wood needed for the meal was separated from the rest of the fuel. This is placed in a pile next to the fire. This was the fuel to be used for the duration of the observation. The pile was then weighed on the digital scale. Fireplace/stove type, cooking area, and ambient conditions (windy, rainy, etc) were noted.

The participant was then asked to make a fire as they normally would, with the method and start time noted and lighting materials weighed. The participant was left to prepare the meal. The timings and food types were noted. When the participant signaled the end of the meal preparation, the time was recorded. The fire was then put out and any burning wood was extinguished by a moist cloth. The remaining fuel was then weighed (no ash). Any burnt wood was also weighed. Any remaining unburned wood in the pile was also weighed. A questionnaire was then administered to further explain the behaviors of the cook and household characteristics (Table 1).

Table 1: Instruments used in the study for data collection.

\begin{tabular}{|c|c|c|}
\hline Activity & Instrument & Description \\
\hline $\begin{array}{l}\text { Household expenditure } \\
\text { on biomass and other } \\
\text { related items }\end{array}$ & $\begin{array}{l}\text { Survey ques- } \\
\text { tionnaire }\end{array}$ & $\begin{array}{l}\text { A well-structured questionnaire was administered to households (primary cook or financial deci- } \\
\text { sion-maker). It was used to measure household composition and demographics, attitudes and priorities, } \\
\text { cooking behaviors (including type(s) of stoves used, fuel used, foods cooked and perception on environ- } \\
\text { mental degradation and climate variability }\end{array}$ \\
\hline Cooking time & Stopwatch & Cooking time was calculated starting from the point that fire was lit to the point all the fire was put out. \\
\hline Weight of biomass & $\begin{array}{c}\text { LCT tree } \\
\text { Digital scale }\end{array}$ & The mass of fuel will be checked before and after a cooking session \\
\hline Record taking & Log sheet & These are 2 forms that the researcher recorded every activity done in the field. \\
\hline
\end{tabular}


Fuel Consumption Rate (FCR), Per capita Biomass Consumption $\left(\mathrm{P}_{\mathrm{c}} \mathrm{BC}\right)$ and Specific Fuel Consumption (SFC) was calculated using:

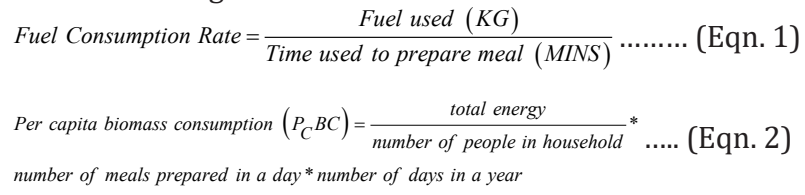

\section{Ethical approval}

The study protocol was reviewed and approved by the Institutional Review Board of the Navrongo Health Research Centre. Oral Informed consent was obtained from all study participants before any data collection.

\section{Results and Discussion}

Twenty (20) UCT's (Ace: $\mathrm{n}=12$ and Jumbo: $\mathrm{n}=8$ ) were completed between November 2018 and March 2019 [see SD table 2]. The data was normally distributed therefore allowing for the use of means and standard deviation to statistically calculate for the difference in consumption. Statistical significance was assessed at a 5\% significance level.

\section{Characteristics of the primary cook and the household}

The social characteristics of the primary cook and the household can be seen in table 2. Most of the primary cooks
(30\%) were between the ages of 36-41 years with all being females. The culture of the people of Northern Ghana frowns on the male gender to be engaged in domestic chores which are seen to be reserved to the female gender. $75 \%$ were Christians, $15 \%$ Muslims, 5\% Traditionalists 5\% had no religious affiliation. This conforms to the national data where $71.2 \%$ of the population are Christians with $17.6 \%$ and $5.2 \%$ being Muslims and traditional religion respectively [8]. Economically, 45\% were self-employed (petty trading (35\%) or in small scale industry (10\%)). About 35\% of the remaining participants stated they were farmers with $10 \%$ stating they were students. $5 \%$ did not engage in any economic activity and $5 \%$ also said they were engaged in casual labor.

$45 \%$ of the primary cooks had no formal education which is about the same as estimated by the Ghana Statistical Service (44.5\%) [8]. $40 \%$ had basic education with only $5 \%$ and $10 \%$ attaining secondary education and College education respectively. $65 \%$ of them were married, $10 \%$ were single while $20 \%$ and $5 \%$ were widowed and divorced respectively. Altogether, $35 \%$ of them were single that is, they have never been married, or have lost their husbands, or divorced. Most of the participants who cook were married. This may be attributed to the fact that they have nuclear families and must cook for them.

In terms of the household size of the participants which is the same as the number of people the meal prepared was going to feed, $65 \%$ of them had a household size of 4-6 people while $35 \%$ represented households with 7 - 9 people (Figure 6).

Figure 6: Household size.

This correlated with the average household size of the area [8] and the relatively large household size implies a large quantity of food needed to be prepared which will mean more fuel and more degradation.

Household general stove ownership was also looked at with $55 \%$ of the households owning 4 stoves while $20 \%, 15 \%$ and $10 \%$ of the participants owned 5, 3 and 6 different stoves respectively (Figure $2 \& 7$ ).

\section{Cooking observation and fuel type}

11 different food types were prepared (Table 2 \& 3). Jollof rice was prepared the most- 5 times (thrice with an Ace and twice 
with a Jumbo stove). TZ was prepared 4 times; 2 each with an Ace and a Jumbo stove while Vegetable soup and Rice balls were both prepared twice but a Jumbo and an Ace each prepared the vegetable soup and both rice balls cooking activity being prepared on a Jumbo. Other meals prepared included; groundnut soup,
"Kaponnu"- (this is a local meal which is prepared using cracked or broken millet or corn, it is prepared in porridge form), Plain rice, Spaghetti, stew, TZ, rice and beans and Tubani (a local meal prepared with beans).

Figure 7: Number of stoves owned by participants.

Table 2: Stoves used in the study.

\begin{tabular}{|c|c|c|}
\hline Stove & Frequency & Percentage (\%) \\
\hline Ace & 12 & 60 \\
\hline Jumbo & 8 & 40 \\
\hline Total & 20 & 100 \\
\hline
\end{tabular}

Table 3: Meals prepared, and stove used.

\begin{tabular}{|c|c|c|c|}
\hline \multirow{2}{*}{ Meal } & \multicolumn{2}{|c|}{ Stove Type } & \multirow{2}{*}{ Total } \\
\cline { 2 - 3 } & Ace & Jumbo & \\
\hline Groundnut soup & $1(5)$ & $0(0)$ & $1(5)$ \\
\hline Jollof & $3(15)$ & $2(10)$ & $5(25)$ \\
\hline “Kaponnu" & $1(5)$ & $0(0)$ & $1(5)$ \\
\hline Rice & $1(5)$ & $0(0)$ & $1(5)$ \\
\hline Rice balls & $0(0)$ & $2(10)$ & $2(10)$ \\
\hline Rice and beans & $0(0)$ & $1(5)$ & $1(5)$ \\
\hline Spaghetti & $1(5)$ & $0(0)$ & $1(5)$ \\
\hline Stew & $1(5)$ & $0(0)$ & $1(5)$ \\
\hline TZ & $2(10)$ & $2(10)$ & $4(20)$ \\
\hline Tubani & $1(5)$ & $0(0)$ & $1(5)$ \\
\hline Vegetable soup & $1(5)$ & $1(5)$ & $2(10)$ \\
\hline Total & $12(60)$ & $8(40)$ & $20(100)$ \\
\hline
\end{tabular}

Although most of the households $(n=12)$ used the Ace stove in this study, 55\% stated firewood as their main source of fuel while $40 \%$ stating charcoal was the main source of fuel. The remaining
$5 \%$ stated they used both fuels equally.

\section{Fuel consumption \\ Mass consumption}

This study was conducted during the dry season (between November 2018 and March 2019) and the consumption rates and patterns reported here apply mainly to that part of the year. This is so because there may exist seasonal variations in fuel choices, sourcing patterns, demand, and availability (Figure 8-10).

For the 12 cooking observations that used charcoal (Ace stove), a total fuel mass (Charcoal) of $3.72 \mathrm{~kg}$ with an average of $0.31 \mathrm{~kg} \pm 0.04$ per cooking activity was consumed while that of the Jumbo stove was calculated at $11.46 \mathrm{~kg}$ of wood that is an average of $1.43 \pm 0.23 \mathrm{~kg}$ of wood per cooking activity. Cumulatively, cooking fuel of mass $15.18 \mathrm{~kg}$ was consumed for all 20 cooking observations; that is the difference of before fuel mass of $41.92 \mathrm{~kg}$ and an after mass of $26.74 \mathrm{~kg}$ (Figure $3 \& 11$ ).

\section{Consumption rate}

Fuel consumption rate which is calculated by fuel used against time (Eqn. 1), for the various meals prepared with the respective stoves (Table 4). the mean consumption rate for the Ace stove was recorded as $0.005 \pm 0.001 \mathrm{~kg} / \mathrm{min}$ meaning the Ace stove burnt $0.005 \mathrm{~kg}$ of fuel every 1 minute whereas the mean consumption rate of the Jumbo stove was calculated as $0.019 \pm 0.002 \mathrm{~kg} / \mathrm{min}$. There was a statistically significant difference $(p<0.001)$ between the fuel consumption rate of the Ace stove and the Jumbo stove. 
Figure 8: Charcoal being measured before cooking.
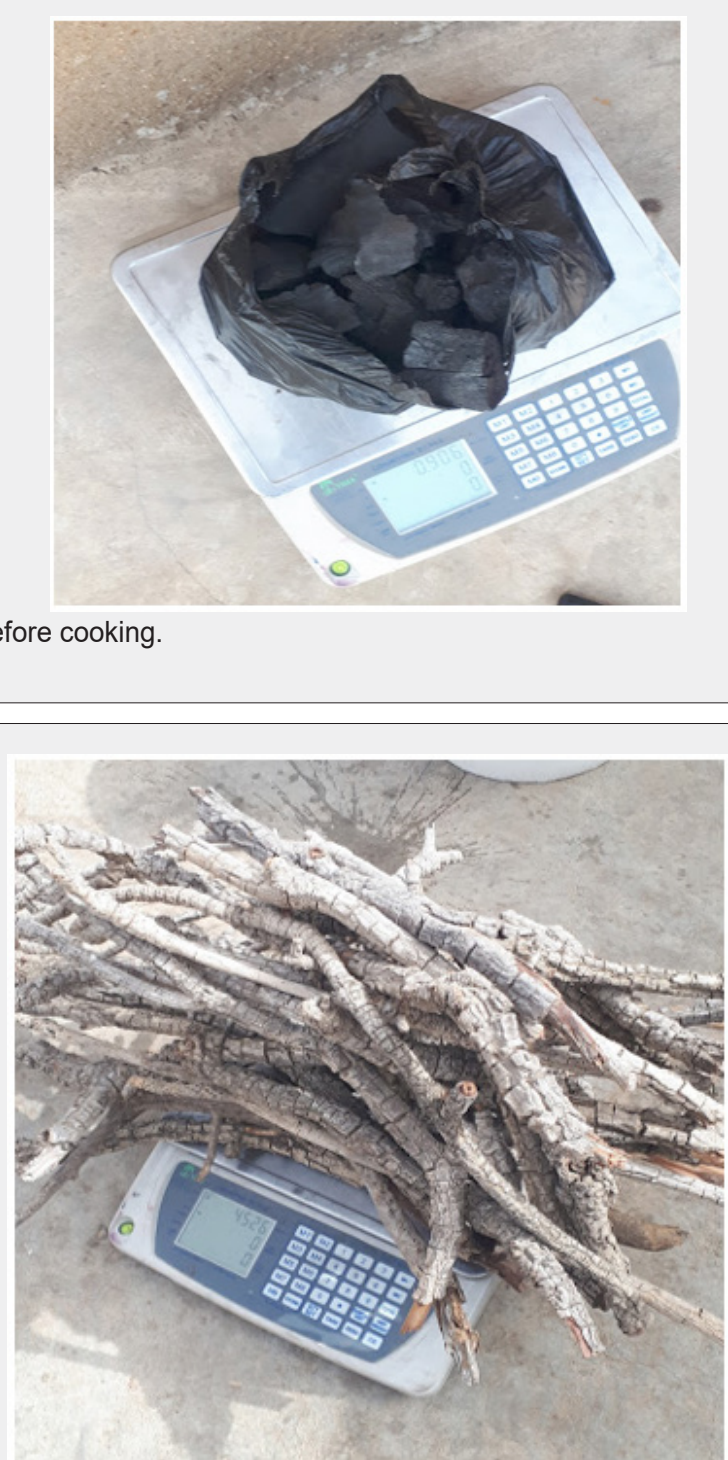

Figure 9: Firewood being measured before cooking

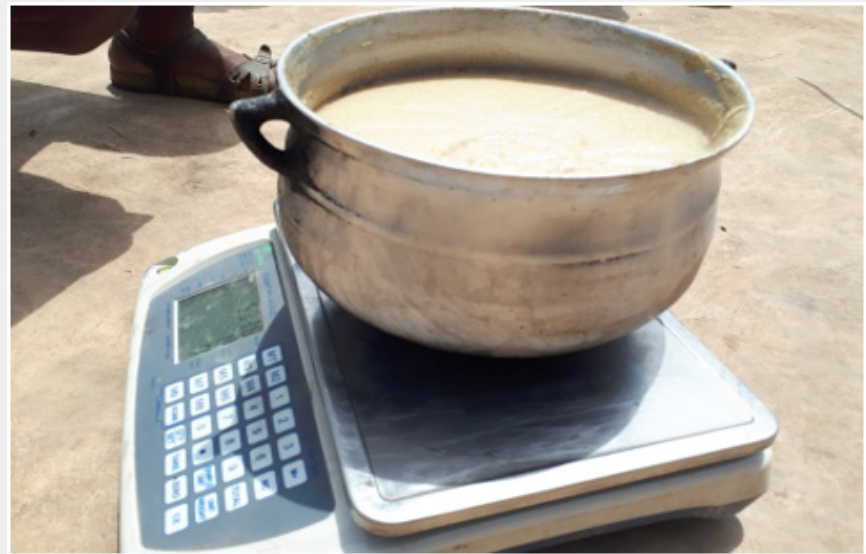

Figure 10: TZ being measured after cooking. 


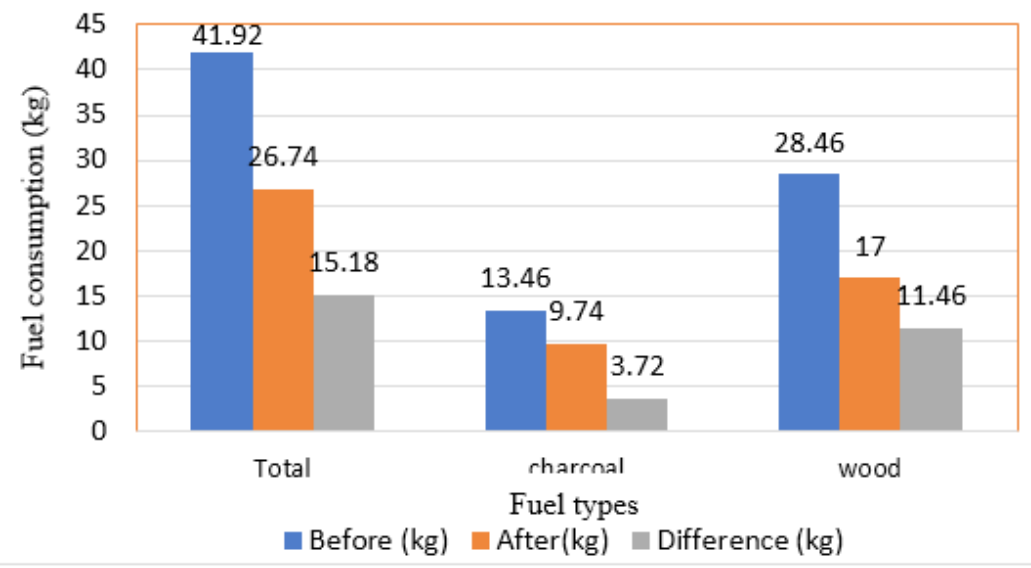

Figure 11: Fuel consumption.

Table 4: The fuel consumption rate for the cooking observations.

\begin{tabular}{|c|c|c|c|c|}
\hline Stove Type & Food & Fuel Used (kg) & Cooking Time (Mins) & Rate(kg/min) \\
\hline JUмво & Rice balls & 2.26 & 71 & 0.032 \\
\hline JUMBO & Jollof & 1.35 & 56 & 0.024 \\
\hline JUMBO & $\mathrm{TZ}$ & 1.66 & 76 & 0.022 \\
\hline JUMBO & Vegetable Soup & 2.21 & 134 & 0.016 \\
\hline JUMBO & Rice and Beans & 1.67 & 73 & 0.023 \\
\hline JUмво & $\mathrm{TZ}$ & 0.73 & 53 & 0.014 \\
\hline JUмBо & Rice Balls & 1.04 & 77 & 0.014 \\
\hline JUMBO & Jollof & 0.54 & 48 & 0.011 \\
\hline Total & & 11.46 & 588 & 0.019 \\
\hline ACE & Kaponnu & 0.14 & 42 & 0.003 \\
\hline ACE & Tubani & 0.26 & 71 & 0.004 \\
\hline ACE & Jollof & 0.14 & 70 & 0.002 \\
\hline ACE & Groundnut Soup & 0.3 & 49 & 0.006 \\
\hline ACE & Jollof & 0.27 & 50 & 0.005 \\
\hline ACE & $\mathrm{TZ}$ & 0.35 & 63 & 0.006 \\
\hline ACE & $\mathrm{TZ}$ & 0.31 & 37 & 0.008 \\
\hline ACE & Jollof & 0.48 & 86 & 0.006 \\
\hline ACE & Stew & 0.3 & 42 & 0.007 \\
\hline ACE & Rice & 0.38 & 85 & 0.004 \\
\hline ACE & Spaghetti & 0.16 & 35 & 0.005 \\
\hline ACE & Vegetable Soup & 0.63 & 202 & 0.003 \\
\hline Total & & 3.72 & 832 & 0.005 \\
\hline
\end{tabular}

\section{Per capita consumption}

The dependence on wood and other non-commercial fuels in the rural areas of most developing countries is often the only cooking fuel source with animal dung and crop residues being the principal non-commercial fuels other than wood and charcoal. To understand the effects of these stoves or household fuel consumption on forest and plants, then, there was the need to calculate for the per capita biomass consumption (Eqn...2). 
It was calculated that a person within a household that prepare one meal a day, will consume an average of 38.06 kg of wood using the jumbo stove and $18.25 \mathrm{~kg}$ of charcoal using the Ace stove per annum. However, a person from a household that prepared 2 meals a day was extimated to consume wood of mass $161.27 \mathrm{~kg}$ annually based on measured consumption from cooking activity whereas a member of a similar household using the Ace stove was estimated to consume charcoal of mass $48.56 \mathrm{~kg}$ per annum. Finally, a member of a household that prepared 3 meals a day was extimated to consume wood using the Jumbo stove of mass $230.66 \mathrm{~kg}$ while that of the Ace stove was calculated at $44.10 \mathrm{~kg}$ per annum. An average household using an Ace stove was therefore estimated to consume charcoal of mass $539.04 \mathrm{~kg}$ per annum whereas that of the Jumbo was estimated to consume firewood of mass $1375.11 \mathrm{~kg}$ per annum (Table 5).

Table 5: Per capita consumption.

\begin{tabular}{|c|c|c|c|c|c|c|c|c|c|c|c|c|c|}
\hline Food & $\begin{array}{l}\text { Stove } \\
\text { Type }\end{array}$ & $\begin{array}{l}\text { Fuel } \\
\text { Type }\end{array}$ & $\begin{array}{l}\text { Fuel } \\
\text { Before }\end{array}$ & $\begin{array}{l}\text { Fuel } \\
\text { After }\end{array}$ & $\begin{array}{l}\text { Fuel } \\
\text { Used }\end{array}$ & $\begin{array}{l}\text { Cooking } \\
\text { Time } \\
\text { (Mins) }\end{array}$ & $\begin{array}{l}\text { Boiling } \\
\text { Time } \\
\text { (Mins) }\end{array}$ & $\begin{array}{c}\text { No. } \\
\text { People }\end{array}$ & $\begin{array}{l}\text { Individual } \\
\text { per-Meal Con- } \\
\text { sumption }\end{array}$ & $\begin{array}{l}\text { Daily In- } \\
\text { dividual } \\
\text { Consump- } \\
\text { tion }\end{array}$ & 1 Meal & 2 Meals & 3 Meals \\
\hline riceballs & JUMBO & WOOD & 4.07 & 1.81 & 2.26 & 71 & 24 & 9 & 0.25111111 & 0.753 & & & 274.967 \\
\hline JOLLOF & JUMBO & WOOD & 3.28 & 1.93 & 1.35 & 56 & 19 & 8 & 0.16875 & 0.338 & & 123.188 & \\
\hline $\begin{array}{c}\text { TUO-ZAAFI } \\
\text { (TZ) }\end{array}$ & JUMBо & WOOD & 3.44 & 1.78 & 1.66 & 76 & 33 & 8 & 0.2075 & 0.623 & & & 227.213 \\
\hline $\begin{array}{l}\text { VEGETA- } \\
\text { BLE SOUP }\end{array}$ & JUMBо & WOOD & 5.38 & 3.17 & 2.21 & 134 & 27 & 6 & 0.36833333 & 0.737 & & 268.883 & \\
\hline $\begin{array}{c}\text { RICE AND } \\
\text { BEANS }\end{array}$ & JUмBо & WOOD & 5.15 & 3.48 & 1.67 & 73 & 29 & 7 & 0.23857143 & 0.477 & & 174.157 & \\
\hline $\begin{array}{c}\text { TUO-ZAAFI } \\
\text { (TZ) }\end{array}$ & JUMBO & WOOD & 2.83 & 2.1 & 0.73 & 53 & 27 & 7 & 0.10428571 & 0.104 & 38.064 & & \\
\hline RICE BALLS & JUMBO & WOOD & 3.42 & 2.38 & 1.04 & 77 & 38 & 6 & 0.17333333 & 0.52 & & & 189.8 \\
\hline JOLLOF & JUMBO & WOOD & 0.89 & 0.35 & 0.54 & 48 & 23 & 5 & 0.108 & 0.216 & & 78.84 & \\
\hline Kaponnu & ACE & $\begin{array}{l}\text { CHAR- } \\
\text { COAL }\end{array}$ & 0.88 & 0.74 & 0.14 & 42 & 21 & 7 & 0.02 & 0.04 & & 14.6 & \\
\hline Tubani & ACE & $\begin{array}{l}\text { CHAR- } \\
\text { COAL }\end{array}$ & 1.67 & 1.41 & 0.26 & 71 & 18 & 6 & 0.04333333 & 0.13 & & & 47.45 \\
\hline JOLLOF & ACE & $\begin{array}{l}\text { CHAR- } \\
\text { COAL }\end{array}$ & 0.82 & 0.68 & 0.14 & 70 & 32 & 6 & 0.02333333 & 0.0467 & & 17.033 & \\
\hline $\begin{array}{l}\text { Groundnut } \\
\text { soup }\end{array}$ & ACE & $\begin{array}{l}\text { CHAR- } \\
\text { COAL }\end{array}$ & 1 & 0.7 & 0.3 & 49 & 13 & 6 & 0.05 & 0.05 & 18.25 & & \\
\hline JOLLOF & ACE & $\begin{array}{l}\text { CHAR- } \\
\text { COAL }\end{array}$ & 0.68 & 0.41 & 0.27 & 50 & 18 & 4 & 0.0675 & 0.135 & & 49.275 & \\
\hline $\begin{array}{l}\text { TUO-ZAAFI } \\
\text { (TZ) }\end{array}$ & ACE & $\begin{array}{l}\text { CHAR- } \\
\text { COAL }\end{array}$ & 0.57 & 0.22 & 0.35 & 63 & 17 & 6 & 0.05833333 & 0.117 & & 42.583 & \\
\hline $\begin{array}{l}\text { TUO-ZAAFI } \\
\text { (TZ) }\end{array}$ & ACE & $\begin{array}{l}\text { CHAR- } \\
\text { COAL }\end{array}$ & 1.21 & 0.9 & 0.31 & 37 & 22 & 5 & 0.062 & 0.124 & & 45.26 & \\
\hline JOLLOF & ACE & $\begin{array}{l}\text { CHAR- } \\
\text { COAL }\end{array}$ & 1.08 & 0.6 & 0.48 & 86 & 40 & 4 & 0.12 & 0.24 & & 87.6 & \\
\hline STEW & ACE & $\begin{array}{l}\text { CHAR- } \\
\text { COAL }\end{array}$ & 0.91 & 0.61 & 0.3 & 42 & 19 & 8 & 0.0375 & 0.113 & & & 41.063 \\
\hline RICE & ACE & $\begin{array}{l}\text { CHAR- } \\
\text { COAL }\end{array}$ & 0.8 & 0.42 & 0.38 & 85 & 38 & 5 & 0.076 & 0.152 & & 55.48 & \\
\hline SPAGHETTI & ACE & $\begin{array}{l}\text { CHAR- } \\
\text { COAL }\end{array}$ & 0.89 & 0.73 & 0.16 & 35 & 16 & 4 & 0.04 & 0.12 & & & 43.8 \\
\hline $\begin{array}{l}\text { VEGETA- } \\
\text { BLE SOUP }\end{array}$ & ACE & $\begin{array}{l}\text { CHAR- } \\
\text { COAL }\end{array}$ & 2.95 & 2.32 & 0.63 & 202 & 62 & 6 & 0.105 & 0.21 & & 76.65 & \\
\hline
\end{tabular}




\section{Specific fuel consumption}

Specific Fuel Consumption (SFC) can be defined as the amount of solid fuel used comparably to achieve a defined task divided by the weight of the task. SFC indicates how efficiently a stove converts chemical energy into heat energy (eqn...3). The mean
SFC was calculated at 0.186 while that of the Jumbo and the Ace are 0.272 and 0.129 respectively. Meaning the Jumbo stove will require $0.27 \mathrm{~kg}$ of firewood to prepare a kilogram of food, while the Ace will only require $0.13 \mathrm{~kg}$ of fuel to prepare the same kilogram of food (Table 6).

Table 6: Specific fuel consumption.

\begin{tabular}{|c|c|c|c|c|}
\hline Stove Type & Meal & Mass of Fuel (kg) & Mass of Food (kg) & SFC (kg/kg) \\
\hline Jumbo & Rice balls & 2.26 & 11.38 & 0.198594 \\
\hline Jumbo & Jollof & 1.35 & 3.03 & 0.445545 \\
\hline Jumbo & $\mathrm{TZ}$ & 1.66 & 6.62 & 0.250755 \\
\hline Jumbo & Vegetable Soup & 2.21 & 4.66 & 0.474249 \\
\hline Jumbo & Rice and Beans & 1.67 & 6.14 & 0.271987 \\
\hline Ace & Kaponnu & 0.14 & 1.94 & 0.072165 \\
\hline Ace & Tubani & 0.26 & 1.12 & 0.232143 \\
\hline Jumbo & $\mathrm{TZ}$ & 0.73 & 4.6 & 0.158696 \\
\hline Ace & Jollof & 0.14 & 1.84 & 0.076087 \\
\hline Ace & Groundnut soup & 0.3 & 2.16 & 0.138889 \\
\hline Ace & Jollof & 0.27 & 1.27 & 0.212598 \\
\hline Jumbo & Rice Balls & 1.04 & 4.87 & 0.213552 \\
\hline Ace & $\mathrm{TZ}$ & 0.35 & 4.2 & 0.083333 \\
\hline Ace & $\mathrm{TZ}$ & 0.31 & 4.22 & 0.07346 \\
\hline Ace & Jollof & 0.48 & 3.95 & 0.121519 \\
\hline Ace & Stew & 0.3 & 2.02 & 0.148515 \\
\hline Ace & Rice & 0.38 & 4.11 & 0.092457 \\
\hline Ace & Spaghetti & 0.16 & 1.88 & 0.085106 \\
\hline Jumbo & Jollof & 0.54 & 3.38 & 0.159763 \\
\hline Ace & Vegetable Soup & 0.63 & 2.95 & 0.213559 \\
\hline
\end{tabular}

\section{Discussion and Conclusion}

The majority of the households owned at least four different stoves with no household stating they had less than three stoves. The practice of stove staking (cooking with more than 1 stove at a time) in the study area is very common as households rely on different stoves for different cooking activities at different seasons. For example, the three-stone stove is mostly used outdoors during the dry season and for preparing larger meals during occasions like funerals. In terms of stove ownership, most of the people owned an Ace stove followed by Jumbo stove with few people owning LPG which is higher in the energy rung as. This outcome was so because households in the study area were located in rural communities which are characterized by poverty hence their inability to purchase and continue to refill the cylinders and lack of access to gas refilling stations.

Juxtaposing observations that involved similar meals the following can be observed from the Table; 3 different food types were prepared using both stoves and these common foods are
Jollof, TZ and vegetable soup. With Jollof, it was prepared 2 times using the Jumbo stove and had a fuel consumption rate of $0.024 \mathrm{~kg} /$ $\min$ and $0.011 \mathrm{~kg} / \mathrm{min}$, while it was prepared 3 times using the Ace and recording a fuel consumption rate of $0.002 \mathrm{~kg} / \mathrm{min}, 0.005 \mathrm{~kg} /$ min and $0.005 \mathrm{~kg} / \mathrm{min}$. The vegetable soup which was prepared using both stoves once also had a consumption rate of $0.016 \mathrm{~kg} /$ min and $0.003 \mathrm{~kg} / \mathrm{min}$ for the Jumbo and Ace respectively. TZ also recorded a consumption rate of $0.022 \mathrm{~kg} / \mathrm{min}$ and $0.014 \mathrm{~kg} / \mathrm{min}$ for the jumbo stove as against $0.005 \mathrm{~kg} / \mathrm{min}$ and $0.008 \mathrm{~kg} / \mathrm{min}$ as recorded by the Ace stove.

The Ace stove was seen to have consumed about $175 \mathrm{~kg}$ of charcoal more than the average Upper East Region's household annual consumption of $364 \mathrm{~kg}$ [9] while that of the Jumbo stove was also estimated to be higher than the regional firewood consumption of 1037 [9]. The two stoves, however, had a superior Per capita consumption as compared to traditional stoves that use similar fuels in neighboring districts in the region [10]. Comparing the SFC with an earlier study done in the arear, Ace stove has the best SFC thus uses less fuel to prepare food. It is followed by 
Philips with wood which has an SFC of 0.19 . The Jumbo stove is only superior to the coal pot and the 3 stone stove which have 0.28 and 0.3 respectively [11]. This implies that switching to the Ace stove or the Jumbo stove will put more stress on the environment than already is as more trees will be needed to produce fuel. And as more trees are being cut, deforestation will occur which will result in the exposure of the soil to erosion and unavailability of trees to act as carbon sinks for toxic emissions. The superior consumption rate of the Ace stove is what accounts for the less mass of fuel that is consumed during the study and this can also be seen in the annual per capita consumption rates as the Ace stove will consume less fuel as compared to the Jumbo stove.

The burning of biomass as fuel has been known as one of the most significant causes of forest deterioration in many developing countries [12]. The rapid loss in forest cover appears to have consequences for the climate system such as drought, flooding, Change in land use, biodiversity and soil fertility loss and land degradation and lowering of water levels in the study area and Ghana as a whole $[13,14]$.

\section{Acknowledgment}

Special thanks to all the participating households in this study for welcoming us into their home. We also acknowledge the Navrongo Health Research Center and all the staff especially Desmond Agao, Shahud Ibn I Azimlogo, Edwin Wangara and Nobert for helping in data collections.

\section{Availability of Data}

The data that support the findings of this study are available from the corresponding author upon reasonable request.

\section{References}

1. Qadir M, Quillérou E, Nangia V, Murtaza G, Singh M, et al. (2014) Economics of salt-induced land degradation and restoration. Natural Resource Forum 38(2): 282-295.

2. Rahman M, Hoque MA (2019) Quality of Flower and Bulb in Tuberose under Saline Condition. Research and Reviews: Journal of Crop Science and Technology 7(3): 1-9.

3. Rehman A, Riaz R, Iqbal M, Shafi J, Ahmad W (2014) Responses of different morphological attribute of Rosa hybrida L. cv. Kardinal to saline water irrigation. Environmental Ecology and Research 2(1): 2126.

4. Reis M, Figueiredo JRM, Paiva R, da-Silva DP, de-Faria CVN, et al. (2016) Salinity in rose production. Ornamental Horticulture 22(2): 228-234.

5. Rodriguez P, Torrecillas A, Morale M, Ortuno M, Sánchez-Blanco M (2005) Effects of $\mathrm{NaCl}$ salinity and water stress on growth and leaf water relations of Asteriscus maritimus plants. Environmental and Experimental Botany 53(2): 113-123.

6. Safi MI, Fardous A, Muddaber M, El-Zuraiqi S, Al-Hadidi L, et al. (2005) Effect of treated saline water on flower yield and quality of roses (Rosa hybrida) and carnation (Dianthus caryophyllus). Science Asia 31: 335339.

7. Saito T, Matsukura C, Ban Y, Shoji K, Sugiyama M, et al. (2008) Salinity stress affects assimilate metabolism at the gene-expression level during fruit development and improves fruit quality in tomato (Solanum lycopersicum L.). Journal of the Japanese Society for Horticultural Science 77(1): 61-68.

8. Salehi H, Kafi M, Eshghi S (2018) Effects of Salinity Stress on Morphological and Physiological Characteristics of Miniature Rose (Rosa chinensis Jacq. var. minima Rehd.). Iranian Journal of Horticultural Science and Technology 19(1): 41-52.

9. Savvas D, Gizas G, Karras G, Lydakis-Simantiris N, Salahas G, et al (2007) Interactions between silicon and $\mathrm{NaCl}$-salinity in a soilless culture of roses in greenhouse. European Journal of Horticultural Science 72(2): 73.

10. Sedibe MM, Khetsha ZP, Malebo N (2013) Salinity effects on external and internal morphology of rose geranium (Pelargonium graveolens $\mathrm{L}$.) leaf. Life Science Journal 10(11): 109-115.

11. Shabala S, Bose J, Fuglsang AT, Pottosin I (2016) On a quest for stress tolerance genes: membrane transporters in sensing and adapting to hostile soils. Journal of Experimental Botany 6(7): 1015-1031.

12. Fox LJ, Grose JN, Appleton BL, Donohue SJ (2005) Evaluation of treated effluent as an irrigation source for landscape plants. Journal of Environmental Horticulture 23(4): 174-178.

13. Frairevelazquez S, Balderas-Hernández VE (2013) Abiotic stress in plants and metabolic responses. In: Vahdati K, Leslie C (Eds.), Abiotic Stress-Plant Responses and Applications in Agriculture. Intechopen, pp. 25-48.

14. Grunberg K, Fernandez-Muñoz R, Cuartero J (1995) Growth, flowering, and quality and quantity of pollen of tomato plants grown under saline conditions. In International symposium on Solanacea for Fresh Market 412: 484-489.

15. Hura T, Szewczyk-Taranek B, Hura K, Nowak K, Pawłowska B (2017) Physiological Responses of Rosa rubiginosa to saline environment. Water, Air, and Soil Pollution 228(2): 81.

16. Küçükahmetler $O$ (2000) The effects of salinity on yield and quality of ornamental plants and cut flowers. Paper presented at the International Symposium on Techniques to Control Salination for Horticultural Productivity 573: 407-414.

17. Li X, Kang Y, Wan S, Chen X, Xu J (2015) Effect of Drip-Irrigation with Saline Water on Chinese Rose (Rosa Chinensis) during Reclamation of Very Heavy Coastal Saline Soil in a Field Trial, Scientia Horticulturae 186: $163-171$

18. Li X, Wan S, Kang Y, Chen X, Chu L (2016) Chinese rose (Rosa chinensis) growth and ion accumulation under irrigation with waters of different salt contents. Agricultural Water Management 163: 180-189.

19. Lou X, Anwar M, Wang Y, Zhang H, Ding J (2020) Impact of inorganic salts on vase life and postharvest qualities of the cut flower of Perpetual Carnation. Brazilian Journal of Biology.

20. Marosz A (2004) Effect of soil salinity on nutrient uptake, growth, and decorative value of four ground cover shrubs. Journal of Plant Nutrition 27(6): 977-989.

21. Massa D, Mattson NS, Lieth HJ (2009) Effects of saline root environment $(\mathrm{NaCl})$ on nitrate and potassium uptake kinetics for rose plants: A Michaelis-Menten modelling approach. Plant and soil 318(1-2): 101112.

22. Mendlinger S, Pasternak D (1992) Effect of time of salinization on flowering, yield and fruit quality factors in melon, Cucumis melo L. Journal of Horticultural Science 67(4): 529-534.

23. Navarro A, Elia A, Conversa G, Campi P, Mastrorilli M (2012) Potted mycorrhizal carnation plants and saline stress: growth, quality and nutritional plant responses. Scientia Horticulturae 140: 131-139. 
24. Niu G, Rodriguez DS, Aguiniga L (2008) Effect of saline water irrigation on growth and physiological responses of three rose rootstocks. Horticultural Science 43(5): 1479-1484.

25. Oki LR Lieth JH (2004) Effect of changes in substrate salinity on the elongation of Rosa hybrida L 'Kardinal' stems. Scientia Horticulturae 101(1-2): 103-119.

26. Perez ARS (2009) Characterizing salinity tolerance in greenhouse roses. Texas A\&M University.

27. Shillo R, Ding M, Pasternak D, Zaccai M (2002) Cultivation of cut flower and bulb species with saline water. Scientia Horticulturae 92(1): 4154.

28. Silberbush M, Lieth JH (2004) Nitrate and potassium uptake by greenhouse roses (Rosa hybrida) along successive flower-cut cycles: a model and its calibration. Scientia Horticulturae 101(1-2): 127-141.

29. Sonneveld C, Voogt W (1983) Studies on the salt tolerance of some flower crops grown under glass. Plant and soil 74(1): 41-52.

30. Tanji K, Grattan S, Grieve C, Harivandi A, Rollins L, et al. (2008) A comprehensive literature review on salt management guide for landscape irrigation with recycled water in coastal southern California. www.salinitymanagement.org 320 .

31. Veatch-blohm ME, Malinowski M, Keefer D (2012) Leaf water status, osmotic adjustment and carbon assimilation in colored calla lilies in response to saline irrigation. Scientia Horticulturae 144: 65-73.

32. Ali E, Bazaid S, Hassan F (2014) Salinity tolerance of taif roses by Gibberellic acid (GA3). International Journal of Science and Research 3(11): 184-192.

33. Amri E, Mirzaei M, Moradi M, Zare K (2011) The effects of spermidine and putrescin polyamines on growth of pomegranate (Punica granatum L. CV Rabbab) in salinity circumstance. International Journal of Plant Physiology and Biochemistry 3(3): 43-49.

34. Aydinsakir K, Tepe A, Buyuktas D (2010) Effects of saline irrigation water applications on quality characteristics of Freesia grown in greenhouse. Akdeniz Üniversitesi Ziraat Fakültesi Dergisi 23(1): 41-46.

35. Cai X, Niu G, Starman T, Hall C (2014) Response of six garden roses (Rosa $\times$ hybrida L.) to salt stress. Scientia Horticulturae 16(8): 27-32.
36. Botia P, Navarro JM, Cerda A, Martinez V (2005) Yield and fruit quality of two melon cultivars irrigated with saline water at different stages of development. European Journal of Agronomy 23(3): 243-253.

37. Zong Y, Yu F, Huang G, Lloyd JM, Yim WWS (2010) The history of water salinity in the Pearl River estuary, China, during the Late Quaternary. Earth Surface Processes and Landforms 35(10): 1221-1233.

38. Cabrera RI (2003) Demarcating Salinity Tolerance in Greenhouse Rose Production. Acta Horticulturae 609: 51-57.

39. Fernandez LA, Pope B, Lee C, Zayed E (1986) Aggressive natural killer cell leukemia in an adult with establishment of an NK cell line. Blood 67(4): 925-930.

40. Cabrera RI (2000) Effect of $\mathrm{NaCl}$ salinity and nitrogen fertilizer formulation on yield and nutrient status of roses. Paper presented at the III International Symposium on Rose Research and Cultivation 54(7): 255-260.

41. Yousefi H, Dalir N, Rahnemaie R, Babaei A (2020) The alleviation of salinity-induced stress by using boron in soilless grown rose. Journal of plant nutrition 43(4): 526-537.

42. Ahmed MAH (2017) Effect of Salinity ( $\mathrm{NaCl}+\mathrm{CaCl} 2)$ and some Soil Additions on Growth, flowering and chemical composition of rose of China (Hibiscus rosa-sinensis L.) plant. Middle East Journal 6(2): 302314.

43. Zeroni M, Gale J (1989) Response of 'Sonia'roses to salinity at three levels of ambient $\mathrm{CO}_{2}$. Journal of Horticultural Science 64(4): 503-511.

44. Chen X, Kang Y, Wan S, Chu L, Li X (2015) Chinese Rose (Rosa Chinensis) Cultivation in Bohai Bay, China, using an Improved Drip Irrigation Method to Reclaim Heavy Coastal Saline Soils. Agricultural Water Management 158: 99-111.

45. Camalle M, Standing D, Jitan M, Muhaisen R, Bader N, et al. (2020) Effect of Salinity and Nitrogen Sources on the Leaf Quality, Biomass, and Metabolic Responses of Two Ecotypes of Portulaca oleracea. Agronomy 10(5): 656.
Your next submission with Juniper Publishers will reach you the below assets

- Quality Editorial service

- Swift Peer Review

- Reprints availability

- E-prints Service

- Manuscript Podcast for convenient understanding

- Global attainment for your research

- Manuscript accessibility in different formats

( Pdf, E-pub, Full Text, Audio)

- Unceasing customer service

Track the below URL for one-step submission https://juniperpublishers.com/online-submission.php 